\title{
Polymer Injection Rehabilitation Technology for Lifting Differential Settlement of Turnout Ballastless Track
}

\author{
Jing Liu ${ }^{1, *}$, Yuanqing $\mathrm{He}^{2}$, Jiahai Zhang ${ }^{2}$, Jian $\mathrm{Hong}^{2}$, Xihua $\mathrm{Wen}^{2}$, Jianhong Xiao ${ }^{2}$, Feng Wang ${ }^{2}$, and Xinguo Zheng ${ }^{1}$ \\ ${ }^{1}$ Railway Engineering Research Institute of China Academy of Railway Sciences, Daliushu Road No.2, 100081, Beijing, China. \\ ${ }^{2}$ Shanghai Railway Bureau, Tianmu East Road, 200071, Shanghai, China.
}

\begin{abstract}
The turnout ballastless track is an advanced track structure with high stability and integrity. However, due to complicated geological conditions, local groundwater level declined, and many other unavoidable objective reasons, the roadbed foundation of some railway lines appeared large uneven settlement deformation, so the above turnout ballastless track concrete structure also experienced uneven settlement accordingly. Compared with ballast track which could be restored by increasing the ballast under the sleepers simply, the smoothness of turnout ballastless track could only be restored by adjusting the thickness of the base plates of fastener system accordingly. But if continuous settlement deformation exceeded the specified allowed adjustable range of the fastener system, the smoothness of ballastless track diminished, the speed of passing trains had to be limited to ensure the safety. In order to solve this global challenging problem, we systematically studied polymer injection rehabilitation technology through a series of indoor reduced scale tests and field full scale simulations with real ballastless track concrete structure. We verified the effect of uplift rehabilitation and filling quality of grouting material through destructive experiment inspection. And combined with engineering practices and its coring samples strength test, the Polymer injection rehabilitation technology for turnout ballastless track in settlement roadbed sections had been studied and developed. This technology could restore the smoothness of railway and the adjustable range of fastening systems without affecting the normal daily operation of the railway lines. Compared with traditional cement grouting technology, this rehabilitation technology possessed significant advantages including small light construction equipment, simple logistics, flexible organization, high uplifting precision, and little additional load. This technology provided valuable technical support and useful references for restoring the smoothness of turnout ballastless track which appeared large uneven settlement deformation.
\end{abstract}

\section{Introduction}

The turnout ballastless track is an advanced track structure with high stability and integrity. The slab ballastless track commonly includes the rail, fastener, concrete track slab, and concrete bottom slab [1-3]. However, in some turnouts of railway lines located in water-rich regions, the foundation of railway lines showed large differential settlement deformation, so the above turnout ballastless slabs also experienced differential settlement accordingly. The smoothness of railway tracks diminished, and the speed of passing trains had to be limited to ensure safety.

To restore the smoothness of the tracks, a complete set of new overall precision uplift rehabilitation technology was systematically studied including special polymer grouting materials (the polyurethane-yielding two-component liquid injection polymer), dedicated miniaturization equipment and construction processes through a series of indoor reduced scale tests and field full scale simulations with real concrete slabs. Combined with field practices, the polymer injection technology for the precision uplifting rehabilitation of uneven settlement of turnout ballastless track had been studied and developed. After rehabilitation, the filling quality of polymer injection under roadbed slabs was examined using $\Phi 50 \mathrm{~mm}$ core samples and the strength of hardened polymer was verified by compressive strength test. Based on these results, a new set of technology and engineering practice had been created to uplift the turnout ballastless track successfully, with no negative effect on existing railway operation, just within the specified daily skylight time (about 4 hours every day) of the railway lines.

This paper introduces polymer injection rehabilitation technology for lifting differential settlement of turnout ballastless track from the grouting materials, construction process, and practical application.

\footnotetext{
*Corresponding author: 705478890@qq.com
} 
These will provide valuable and useful references for quick rehabilitation of differential settlement of turnout ballastless track.

\section{Polymer Grouting material}

The grouting material applied is a kind of polyurethaneyielding two-component (" $\mathrm{A}$ " and "B") liquid injection polymer mixture. After mixing, the material will gel and react to form the resulting polyurethane solid foam within a short time (see Fig.2). The one component "A" is composed of polyisocyanate prepolymer mixture without any VOC (volatile organic compounds). The other component " $\mathrm{B}$ " is composed of polyols and catalysts mixture such as polyetherpolyols and tertiary amines without any VOC. The polyurethane grouting is based on three dimensional network solid polymer with high strength that is produced with generation of heat and increase of volume when the liquid isocyanate compound is mixed with a liquid polyol compound [45]. This solid polymer foam is able to expand and form different volumes as needed. Therefore, the technical information on the chemical and physical behaviors of the liquid injection materials and those of the polyurethane solid foam application are supposed to be very important for an effective application of this grouting material [6-8]. The physical and mechanical properties of the polymer grouting materials are listed in Table 1. Compared with other grouting materials, the polymer grouting material has the following features:

(1) Designed to develop hydraulic lift efficiently

The hydraulic uplifting for concrete structure of ballastless track is largely realized by the expansibility of the grouting materials. The hydraulic uplifting force is determined by the foaming ratio (or volume expansion) of the polymer which can be controlled precisely.

(2) High ability of permeation, diffusion and filling

With a certain grouting process, the diffusion diameter of the grouting materials can reach up to more than 5 meters and it also has a certain volume expansion (the free expansion ratio can reach up to 20:1). Therefore, the filling ability of the grouting materials is outstanding. Meanwhile, it can compact the foundation substructure (Namely, graded broken stone layer under the concrete roadbed slab) in the filling range to form the sandwich structure densely and firmly (see Fig. 1).

(3) Filling range controllable

After mixing of two component grouting materials, the liquid state will transform into plastic state and then the solid state within a short time. Thus, the filling range is easy to adjust by controlling the reaction speed of two component grouting materials. Therefore, it is more convenient to construction with no need to set special curtains to prevent the slurry from overflow.

(4) Low density and weight

The structure density formed by this grouting material is around $100 \mathrm{~kg} / \mathrm{m} 3 \sim 300 \mathrm{~kg} / \mathrm{m} 3$, far less than the water density. So compared with cement grouting materials, it does not increase the additional structural load significantly.
Table 1. Physical and mechanical properties of this polymer grouting material

\begin{tabular}{|c|c|c|c|}
\hline No. & Items & Units & Index Value \\
\hline 1 & Setting time & $\mathrm{s}$ & $5 \sim 10$ \\
\hline 2 & Drying time & $\mathrm{s}$ & $10 \sim 30$ \\
\hline 3 & $\begin{array}{l}\text { Time of reaching } 90 \% \\
\text { of ultimate strength }\end{array}$ & $\min$ & $\leq 10$ \\
\hline 4 & $\begin{array}{l}\text { Compressive strength } \\
\text { in free expansion } \\
\text { condition }\end{array}$ & $\mathrm{MPa}$ & $>1.0$ \\
\hline 5 & $\begin{array}{l}\text { Tensile strength in } \\
\text { free expansion } \\
\text { condition } \\
\end{array}$ & $\mathrm{MPa}$ & $>1.0$ \\
\hline 6 & Expansion rate & $\%$ & $>300$ \\
\hline 7 & Elongation rate & $\%$ & $\geq 0.3 \%$ \\
\hline 8 & $\begin{array}{l}\text { Fatigue resistance } \\
\text { performance } \\
(10000000 \text { times })\end{array}$ & / & $\begin{array}{c}\text { No cracking, } \\
\text { Residual } \\
\text { deformation }<5 \%\end{array}$ \\
\hline 9 & $\begin{array}{l}\text { Acid and alkali } \\
\text { resistance } \\
\text { performance }(\mathrm{pH} \\
\text { value } 2 \sim 13)\end{array}$ & / & $\begin{array}{c}\text { Compression } \\
\text { retention rate } \geq 80 \%\end{array}$ \\
\hline 10 & $\begin{array}{l}\text { Freezing resistance } \\
\quad(300 \text { times })\end{array}$ & / & $\begin{array}{l}\text { No exfoliation, } \\
\text { Residual } \\
\text { deformation } \geq 70 \%\end{array}$ \\
\hline 11 & $\begin{array}{c}\text { Environmental } \\
\text { protection } \\
\left(20^{\circ} \mathrm{C}, \text { Soaked in }\right. \\
\text { water for } 30 \text { days })\end{array}$ & / & $\begin{array}{l}\text { Soaking water } \\
\text { meets drinking } \\
\text { water standard }\end{array}$ \\
\hline
\end{tabular}

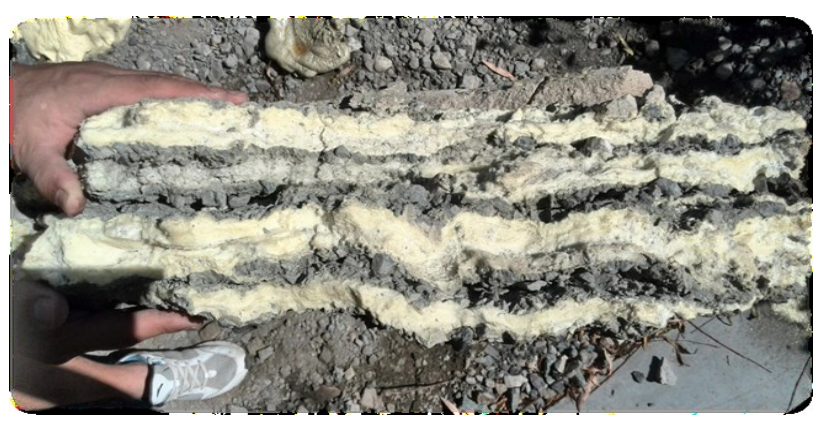

Fig. 1. Sandwich structure of polymer foam layer and graded broken stone layer.

(5) Fast in setting and hardening, fast in strength development

The grouting material can reach up to more than $90 \%$ of the design strength just within 10 minutes, which can completely meet the strength requirements for railway line operation. As a result, the traffic can be resumed in time after the uplifting of concrete structure.

(6) High volume stability

It almost has no volume shrinkage after the hardened structure formed and will have the feature of a perfect elastomer before $80 \%$ of the failure load.

(7) High durability 
The hardened polymer grouting materials with closed cell structure (see Fig. 2) possesses a high durability property with high water tightness, frost resistance and chemical erosion resistance.

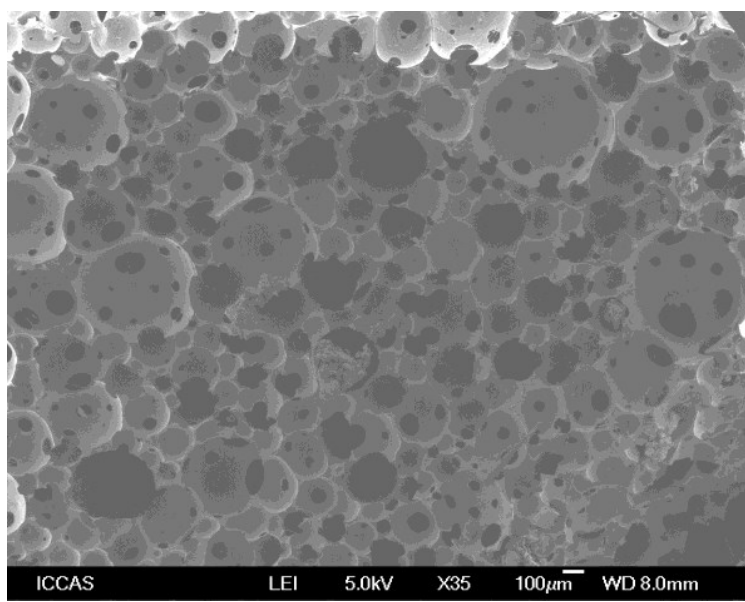

Fig. 2. Polyurethane solid foam closed cell microstructure morphology

\section{Practical Application}

One railway line started operation in 2010 within a range of 350 meters including the turnout ballastless track had the differential settlement problems. The maximum settlement deformation was $80 \mathrm{~mm}$. The railway speed in this settlement section had to be limited to $160 \mathrm{~km} / \mathrm{h}$ to ensure safety.

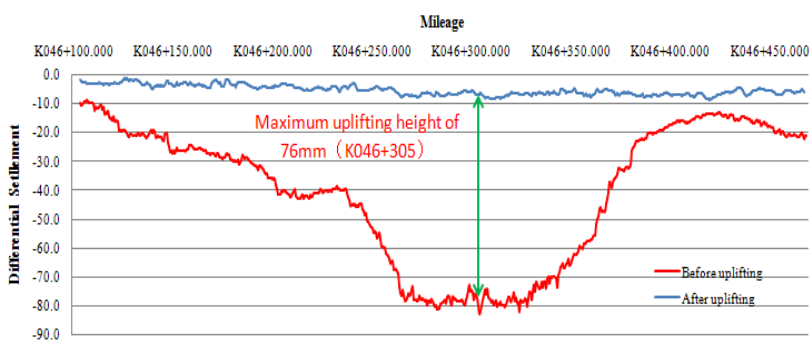

Fig. 3. Comparison of the elevation of turnout ballastless track before and after uplifting rehabilitation.

In 2017 , the roadbed slab settlement of this turnout ballastless track was rehabilitated by this polymer injection technology. During rehabilitation, when the grouting equipment operated smoothly and the polymer materials reached a stable physical and mechanical performance, the grouting uplifting rehabilitation was carried out according to the specified grouting procedure. The electronic levels were adopted to monitor the rail elevation change and the total station was adopted to monitor the center line misalignment of concrete structure (See Fig. 4). The turnout ballastless track was lifted to the designed elevation by rational arrangement of the injection holes position and the proper adjustment of polymer material properties. When the uplifting reached the expected height, grouting should be stopped and the high-strength non-shrinking cement material was used to block up the injection holes.
It only took 60 days to fulfill this repair work of this settlement section. The concrete structure had no cracking due to uplifting rehabilitation. The accuracy of uplifting elevation for the ballastless track structure could be up to $\pm 1 \mathrm{~mm}$. The rehabilitation (only 4 hours every day) had not disturbed the following operation of the railway line next day. The site coring sampling test (see Fig.4) showed that the concrete ballastless track structure gaps were full of polymer grouting materials with high strength (the compressive strength of coring polymer tested in lab was $20 \mathrm{MPa}$, higher than the design requirement of roadbed).

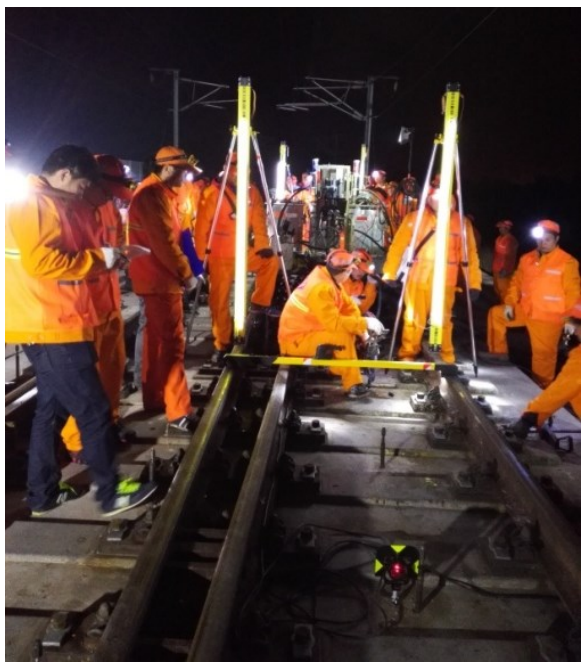

Fig. 4. Polymer injection rehabilitation for lifting differential settlement of turnout ballastless track

After rehabilitation, the smoothness of the track was improved significantly. The maximum uplifting height of the concrete structure was up to $76 \mathrm{~mm}$ (No cracking during uplifting rehabilitation). The railway speed in this section had recovered to the design speed and the dynamic response of the ballastless track in this section which tested by the comprehensive detection train showed no abnormality.

\section{Conclusions}

The Polymer injection rehabilitation technology for lifting differential settlement of turnout ballastless track has the advantages of rapid restoration and good effects which can neither affect the track structure stress adversely nor affect the traffic safety. It is also a rapid, simple and practical method to rehabilitate the ballastless track of the settlement just using daily skylight time (only 3 hours every day), no disturbance of railway line operation and little destruction to the existing concrete structure. The polymer grouting materials is promising in the settlement rehabilitation of the ballastless track even in water-rich environment.

The accuracy of uplifting elevation for the track structure can be up to $\pm 1 \mathrm{~mm}$. The properties of these two component grouting materials and the resulting solid foam are very versatile and with stringent quality control, this uplift rehabilitation technology can be more 
effectively and successfully applied to many other construction projects.

This research was supported by China Railway Corporation Science and Technology Research and Development Program under Grant No. 2017G002-D, 2017G002-C and 2016G001-A, China Academy of Railway Science Foundation under Grant No. 2016YJ024 and Shanghai Railway Bureau Foundation under Grant No.2016-17.

\section{References}

1. X. G. Zheng, J. Liu, et al. Railway Engineering. Preparation of Cement Emulsified Asphalt Mortar for CRTS IISlab Ballastless Track. 8, 121-124 (2009) (in Chinese).

2. S. H. Jin, X. F. Chen, et al. China Railway Science. Key technologies of CA mortar for slab track. 27(2), 20-24 (2006) (in Chinese).

3. Z. Zeng, X. G. Zheng, et al. Railway Engineering. Construction technology of cement-emulsified asphalt mortar used in CRTS II ballastless slab track. 9, 97-100 (2009) (in Chinese).
4. O. Buzzi, S. Fityus, Y. Sasaki, et al. Mechanics of Materials. Structure and properties of expanding polyurethane foam in the context of foundation remediation in expansive soil. 40, 1012-1021 (2008)

5. D. Seo, J.R. Youn. Polymer. Numerical analysis on reaction injection molding of polyurethane foam by using a finite volume method. 46, 6482-6493 (2005)

6. B. Chun, D. Ryu. Journal of Civil Engineering A study on applications of polyurethane injection material for ground improvement. 4(2), 113-118 (2000)

7. Aksoy CO. International Journal of Rock Mechanics and Mining Sciences. Chemical injection application at tunnel service shaft to prevent ground settlement induced by groundwater drainage: a case study. 45, 376-383 (2008)

8. A. Varol, S. Dalgic. Tunneling and Underground Space Technology. Grouting applications in the Istanbul metro, Turkey. 21, 602-612 (2006) 